\title{
Equilibrium, Thermoanalytical and Spectroscopic Studies to Characterize Phytic Acid Complexes with Mn(II) and Co(II)
}

\author{
Ligia De Carli, ${ }^{a}$ Egon Schnitzler, ${ }^{a}$ Massao Ionashiro, ${ }^{b}$ Bruno Szpoganicz ${ }^{c}$ and Neiva Deliberali Rosso $* a$ \\ ${ }^{a}$ Departamento de Química, Universidade Estadual de Ponta Grossa, UEPG, Av. Carlos Cavalcanti 4748, \\ 84030-900 Ponta Grossa-PR, Brazil \\ ${ }^{b}$ Instituto de Química, Universidade Estadual Paulista, UNESP, C.P. 355, 14801-970 Araraquara-SP, Brazil \\ 'Departamento de Química, Universidade Federal de Santa Catarina, UFSC, 88040-900 Florianópolis-SC, Brazil
}

\begin{abstract}
Estudos potenciométricos foram realizados para determinar o grau de ligação do ácido fítico com os íons $\mathrm{Co}(\mathrm{II})$ e o $\mathrm{Mn}(\mathrm{II})$, na ausência de dioxigênio. As constantes de equilíbrio para as principais espécies formadas são relatadas, e os resultados são representados na forma de diagramas de distribuição mostrando a concentração individual dos complexos como uma função do pH. Os valores das constantes de formação dos complexos foram elevados para as espécies em que o ligante encontra-se mais desprotonado. Os dados potenciométricos indicam que a espécie $\left[\mathrm{MH}_{4} \mathrm{~L}\right]^{6-}$, encontra-se totalmente formada em $\mathrm{pH}$ 7,0 e a partir destes dados os complexos de Mn(II) e Co(II) com o ácido fítico foram sintetizados no estado sólido. Análises de infravermelho, termogravimetria e calorimetria exploratória diferencial foram utilizadas para caracterizar e investigar o comportamento térmico destes compostos. Os resultados conduziram a informações sobre composição, desidratação, estabilidade e decomposição térmica dos complexos.
\end{abstract}

Potentiometric studies were carried out to determine the binding degree of phytic acid with $\mathrm{Co}(\mathrm{II})$ and $\mathrm{Mn}$ (II) ions, in the absence of dioxygen. Equilibrium constants for all major complexes formed are reported, and the results are presented in the form of distribution diagrams showing the concentrations of individual complexes as a function of $\mathrm{pH}$. The formation constants of the complexes show higher values for the species in which the ligand was more deprotonated. Potentiometric data indicates that the species $\left[\mathrm{MH}_{4} \mathrm{~L}\right]^{6-}$, was totally formed at $\mathrm{pH} 7.0$ and the complexes were synthesized from this data. A solid state complex of $\mathrm{Mn}$ (II) and $\mathrm{Co}$ (II) with phytic acid was synthesized. Thermogravimetry, differential scanning calorimetry, and infrared spectroscopy were used to investigate and characterize the thermal behavior of these compounds. The results led to information on the composition, dehydration, thermal stability and thermal decomposition of the isolated complexes.

Keywords: phytic acid, manganese (II) complexes, cobalt (II) complexes, equilibrium studies, thermal behavior

\section{Introduction}

Phytic acid is a phosphorylated derivative, chemically named myo-inositol 1,2,3,4,5,6-hexakis(dihydrogen) phosphate, and known as $\mathrm{InsP}_{6}$. The synthesis of $\mathrm{InsP}_{6}$ in vegetable derives from glucose 6-phosphate, that by syntase $\operatorname{Ins}(3) \mathrm{P}_{1}$ enzyme action, goes on via phosphorylated derivative mono, di, tri, tetra, penta and hexa phosphate of cyclic alcohol myo-inositol. ${ }^{1}$ This acid has important physiological functions in plant life cycles and the most

*e-mail: ndrosso@uepg.br important is phosphorous storage. At seed maturity, $60 \%$ of phosphorous is related to the presence of phytate. ${ }^{2}$ Phytic acid also exerts cellular metabolism effects due to its capacity to combine with multivalent cations, which control cellular processes. ${ }^{3}$ Several experiments have shown the antioxidant effects of phytic acid. The effect of $\mathrm{InsP}_{6}$ on lipid peroxidation of meat products has been investigated and the antioxidant action is concentration and $\mathrm{pH}$ dependent. ${ }^{4,5}$ The authors of this research suggested that the addition of small amounts of phytic acid may inhibit lipid peroxidation both by accelerating autoxidation of ferrous to ferric ion and by forming catalytically inactive iron chelates. 
The capability of phytic acid to chelate metallic ions has led several investigators to evaluate the possibility of this acid being able to act in environmental accident control. ${ }^{6}$ They studied the ability of phytic acid to immobilize PVP (poly-4-vinylpyridine) resin for subsequent use to adsorb heavy metals. The authors concluded that this compound showed high adsorption capacity for heavy metals at $\mathrm{pH}$ 6.5 and $25^{\circ} \mathrm{C}$. Another proposed use for phytic acid is as an inhibitor of copper corrosion in potable water, using $\mathrm{Ca}$, $\mathrm{Mg}$ and Na salt derivative of phytic acid. These phytates were used in the simulation of domestic wastewater at $\mathrm{pH} 6.8$, and the study demonstrated that the corrosion was delayed due to hydrolysis and the formation of insoluble copper chelates. ${ }^{7}$ In a new study the phytic acid was used to build a modified platinum electrode and single-walled carbon nanotube. This electrode was tested for the selective determination of dopamine in the presence of ascorbic and uric acids. According to the authors the modified electrode demonstrated good enhancements of sensitivity and selectivity. ${ }^{8}$

Nutritionally, phytic acid is important because it interacts with metallic bivalent ions forming stable complexes. ${ }^{9-11}$ Phytic acid has been found to inhibit the oxidative damage caused to DNA through the chelating action with metals, inhibiting the generation of highly reactive species, such as free radicals. Phytic acid is expected to effectively inhibit oxidative DNA damage by chelating $\mathrm{Cu}$ (II) as well as $\mathrm{Fe}$ (II) and $\mathrm{Fe}$ (III). Thus, phytic acid may inhibit the generation of highly reactive species from $\mathrm{H}_{2} \mathrm{O}_{2}$ by chelating transition-metal ions, resulting in chemoprevention of cancer. ${ }^{12}$ This review assesses the potential of $\mathrm{InsP}_{6}$ being a wide-ranging regulator of many important cellular functions. ${ }^{13}$ While another review will give a general overview of the structure and function of phytic acid and phytases, phytic acid as a component of food and animal feed, industrial applications, and medicinal qualities in order to better understand the complete phytic acid system. ${ }^{14}$ This article shows new evidence in that the consumption of phytate reveals several positive effects on human health as well. The authors reported that dietary phytate prevents kidney stone formation, protects against diabetes mellitus, caries, atherosclerosis and coronary heart disease as well as against a variety of cancers. ${ }^{15}$

The present study examined the inhibitory effects of pyrophosphate, etidronate, and phytate on bovine pericardium calcification in vitro. The data indicated that phytate was the most potent inhibitor of calcification, and the effects of this agent were apparent at levels as low as $0.25 \mathrm{mg} \mathrm{L}^{-1} .{ }^{16}$ Excessive iron can induce oxidative stress subsequently causing degradation of nigral dopaminergic neurons in Parkinson's disease (PD) this research showed the protective effect of a naturally occurring iron chelator, phytic acid ( $\left.\mathrm{IP}_{6}\right)$, on 1-methyl-4-phenylpyridinium induced cell death in immortalized rat mesencephalic/dopaminergic cells. The results demonstrated a significant neuroprotective effect of phytate in a cell culture model of PD. ${ }^{17}$

To define the structural aspect of myo-inositol phosphate, ${ }^{13} \mathrm{C}$ NMR, ${ }^{31} \mathrm{P}$ NMR techniques and RAMAN spectroscopy were used. Results showed that the action of phytic acid is dependent on $\mathrm{pH}$. Thus, at $\mathrm{pH}$ values below 9.0, one phosphate is in the axial form and five are in the equatorial form (1ax/5eq), as shown in Scheme 1. It is believed that the presence of four or more equatorial phosphates in the inositol ring results in the conformation change from $1 \mathrm{ax} / 5 \mathrm{eq}$ to $5 \mathrm{ax} / 1 \mathrm{eq}$ at high $\mathrm{pH} .{ }^{18-20}$

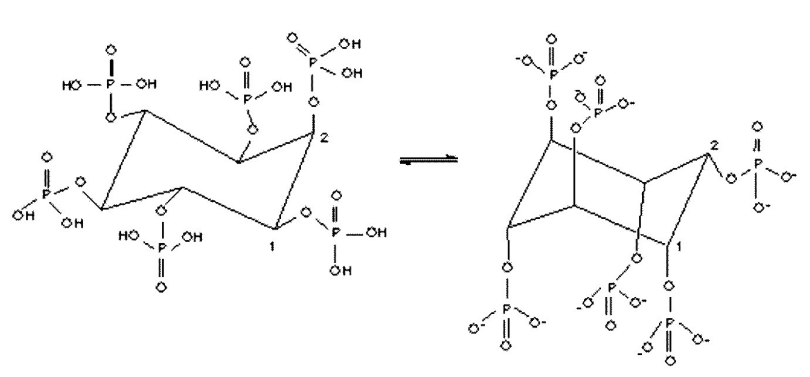

Scheme 1. Phytic acid conformation according $\mathrm{pH}$.

Several minerals and trace elements present in food form soluble and non-soluble complexes with phytic acid in the human small intestine. The interaction of phytic acid with trace elements, depending on the amount in the organism, affects the absorption of these minerals. ${ }^{21}$ The interaction mechanism is related to the phytic acid structure. ${ }^{22}$ Since phytic acid coordinates through phosphate groups, the resulting structure is a chelate compound. In vitro studies indicate that phosphate hexakisdihydrogen, $\mathrm{InsP}_{6}$ and its derivatives $\mathrm{InsP}_{5}$, $\operatorname{InsP}_{4}$, and $\mathrm{InsP}_{3}$, are bound to metallic ions at similar $\mathrm{pH}$ values to that of the duodenum. Thus, researchers have concluded that the binding capacity of phosphate inositol to metallic ions is dependent on the quantity of deprotoned phosphate groups. ${ }^{23}$

Studies concerning phytic acid in aqueous solution showed that only 10 of 12 hydrogens of its molecule are substituted. In addition, they revealed that phytate ion protonation is dependent on both the ionic medium and ionic strength. ${ }^{24}$ In another study, researchers determined phytic acid protonation enthalpies and entropies and concluded that entropic values for each protonation constant are significantly higher than the corresponding enthalpy changes. ${ }^{25}$ This ligand has also been used in interesting applications, such as in multilayer films with titanium dioxide for hemoglobin adsorption. ${ }^{26}$ It has also been used to prevent metal pipe 
corrosion, as the phytic acid and its salts showed very high performance when compared with some traditional and environmentally toxic inhibitors. ${ }^{27}$ Studies showed that phytic acid interacts through phosphate groups with different metallic ions, to form heterometallic complexes of $\mathrm{Zn}$ (II) and $\mathrm{Mn}(\mathrm{II}){ }^{28}$ The complexation of $\mathrm{Zn}$ (II) and $\mathrm{Mn}$ (II) by the phosphate groups of $\mathrm{IP}_{6}$ is demonstrated by the NMR and X-ray photoelectron spectroscopy (XPS) results. The ${ }^{13} \mathrm{C}$ NMR data showed a conformation for $\mathrm{IP}_{6}$ consisting of five equatorial phosphate groups and one axial group showing only one chemical environment for $\mathrm{Zn}$ (II) and two for Mn(II). Studies highlight the interaction of phytic acid with multivalent cations, such as $\mathrm{Fe}$ (III), $\mathrm{Hg}$ (II) $\mathrm{Cd}$ (II), $\mathrm{Ca}(\mathrm{II}), \mathrm{Mg}$ (II) and $\mathrm{Cu}$ (II). ${ }^{29-33}$ Results indicated a high stability constant for Fe(III), corresponding to complexes with highly deprotonated $\mathrm{InsP}_{6}$ species. Phytic acid also showed very good sequestering ability toward $\mathrm{Hg}$ (II), even in the presence of considerable excesses of chloride ions, another ligand that interacts strongly with mercury. Recent work reported on the data of interaction between $\mathrm{Sr}^{2+}$ and $\mathrm{Ba}^{2+}$ with phytic acid, which behaved similarly to $\mathrm{Mg}^{2+}$ and $\mathrm{Ca}^{2+}$, but giving even less soluble systems. ${ }^{34}$ It also described phytic acid interactions with $\mathrm{Li}^{+}, \mathrm{Na}^{+}, \mathrm{K}^{+}, \mathrm{Mg}^{2+}, \mathrm{Ca}^{2+}, \mathrm{Sr}^{2+}$, and $\mathrm{Ba}^{2+}$ in a non-interacting medium: these depended strongly on cation charge but only weakly on ionic radius within each series.

A study gathered and analyzed information about the formation and stability of phytate complexes in solution. ${ }^{35}$ According to the authors regarding to the thermodynamic data on phytate complexes in solution, some are lacking, while some others exhibit large discrepancies between different authors. The review aimed at identifying the most accurate data on phytate coordination in solution. Crea $e t$ $a l .{ }^{36}$ investigated thermodynamic parameter for zinc(II) sequestration at different ionic strengths and temperatures. The sequestering ability of phytate toward zinc(II) was quantified in various conditions, and the dependence of these parameters on temperature, $\mathrm{pH}$, and ionic strength was modeled by simple empirical equations. These equations allow the determination of zinc(II) sequestration by phytate in a very wide range of conditions of environmental and biological interest.

This paper describes the equilibrium association of the metal ions $\mathrm{Mn}$ (II) and $\mathrm{Co}$ (II) with phytic acid through equilibrium, thermal and spectroscopy studies.

\section{Experimental}

\section{Materials}

Phytic acid in form of dipotassium salt $\left(\mathrm{C}_{6} \mathrm{H}_{16} \mathrm{O}_{24} \mathrm{P}_{6} \mathrm{~K}_{2}\right)$, potassium chloride (supporting electrolyte), manganese(II) chloride tetrahydrate $\left(\mathrm{MnCl}_{2} \cdot 4 \mathrm{H}_{2} \mathrm{O}\right)$, cobalt(II) chloride hexahydrate, $\left(\mathrm{CoCl}_{2} \cdot 6 \mathrm{H}_{2} \mathrm{O}\right)$, ethylenediaminetetraacetic acid (EDTA) and potassium acid phthalate were reagentgrade materials, from Sigma and Merck, and were used without further purification. The stock solutions of Mn(II) and $\mathrm{Co}$ (II) were standardized by titration according to methods in the literature. ${ }^{37} \mathrm{~A}$ carbonate-free solution of $0.100 \mathrm{~mol} \mathrm{~L}^{-1} \mathrm{KOH}$ was prepared from Baker Diluit-It ampoules and was standardized by titration with standard potassium phthalate.

\section{Potentiometric equilibrium measurements}

Potentiometric studies of phytic acid in the absence and presence of manganese(II) and cobalt(II) were carried out with a Micronal model B474 research $\mathrm{pH}$ meter fitted with blue-glass and $\mathrm{Ag} / \mathrm{AgCl}$ reference electrodes. The potentiometric apparatus was calibrated with standard $\mathrm{HCl}$ and $\mathrm{KOH}$ solutions to read $-\log \left[\mathrm{H}^{+}\right]$directly, ${ }^{38}$ and the $\mathrm{pKw}$ for water at $\mu=0.100 \mathrm{~mol} \mathrm{~L}^{-1}$ was 13.70 at $36.0^{\circ} \mathrm{C}$. Samples of about $0.100 \mathrm{mmol}$ of phytic acid were diluted with $60 \mathrm{~mL}$ of distilled water $\left(\mathrm{KMnO}_{4}\right)$ in a sealed thermostated vessel at $36.0 \pm 0.1^{\circ} \mathrm{C}$. The experimental solution of phytic acid alone, adjusted to $0.100 \mathrm{~mol} \mathrm{~L}^{-1}$ ionic medium with $\mathrm{KCl}$, was titrated with $0.100 \mathrm{~mol} \mathrm{~L}^{-1}$ standard $\mathrm{CO}_{2}$-free $\mathrm{KOH}$ until the $\mathrm{pH}$ reached about 11, providing 108 points. Solutions containing phytic acid plus $\mathrm{Co}$ (II) and phytic acid plus $\mathrm{Mn}$ (II) were studied potentiometrically at molar ratios of $2: 1$, with $0.200 \mathrm{mmol}$ of phytic acid, $0.100 \mathrm{mmol}$ of $\mathrm{Co}(\mathrm{II})$, and $0.100 \mathrm{mmol} \mathrm{Mn}(\mathrm{II})$. The solutions containing phytic acid and $\mathrm{Co}(\mathrm{II})$ or $\mathrm{Mn}$ (II) were then titrated with standard $\mathrm{KOH}$ solution until the $\mathrm{pH}$ was around 10.5, providing 98 points. All systems were studied under anaerobic conditions, purged with purified argon using two $0.100 \mathrm{~mol} \mathrm{~L}^{-1} \mathrm{KOH}$ solutions. Computations of the triplicates were all carried out with the BEST-7 program, and the species diagrams were obtained with SPE and SPEPLOT programs. ${ }^{38}$ All equilibria, as well as hydrolysis of the metal ion, were considered in the calculation of the constants. ${ }^{39}$

Synthesis of complexes: $\mathrm{K}_{6}\left[\mathrm{Mn}\left(\mathrm{C}_{6} \mathrm{H}_{10} \mathrm{O}_{24} \mathrm{P}_{6}\right)\right]$ and $\mathrm{K}_{6}\left[\mathrm{Co}\left(\mathrm{C}_{6} \mathrm{H}_{10} \mathrm{O}_{24} \mathrm{P}_{6}\right)\right]$

Complexes of phytic acid with bivalent manganese and cobalt ions have been synthesized using species distribution curves with $\mathrm{pH}$ 7.0. Thus, the synthesis of the complexes was carried out by adding $0.2 \mathrm{mmol}$ of phytic acid in $5 \mathrm{~mL}$ of distilled water to $0.1 \mathrm{mmol}$ of the respective metal-ion

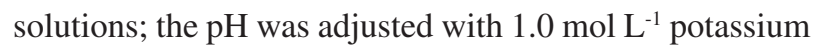
hydroxide solution with continuous stirring for $2 \mathrm{~h}$. The 
resulting solutions were kept at room temperature and after 14 days a glass-like solid for the manganese complex and a blue solid for the cobalt complex were obtained. These complexes were kept over silica gel in desiccators for 1 week.

\section{Infrared and thermal analysis}

Infrared spectra were recorded on a Spectrum 8400 FTIR Shimadzu spectrophotometer. Samples were prepared as KBr pellets. For the thermal analysis TG/DTG and DSC curves were obtained with two Shimadzu thermal analysis systems, model TG-60 and DSC-60, and the purge gas was an air flow of $50 \mathrm{~mL} \mathrm{~min}{ }^{-1}$. A heating rate of $20^{\circ} \mathrm{C}$ $\mathrm{min}^{-1}$ was adopted, with samples weighing about $12 \mathrm{mg}$ (TG) and $7 \mathrm{mg}$ (DSC). Alumina and aluminum crucibles, the latter with covers, were used for the TG and DSC, respectively.

\section{Results and Discussion}

\section{Equilibrium studies}

The potentiometric equilibrium curves are illustrated in Figures 1 and 2 where each curve represents a separate experiment. The shapes of the curves give qualitative information of solution stoichiometry and suggest possible species that could be present. The upper curve in Figure 1 reveals that phytic acid gives rise to three buffer regions; one around $\mathrm{pH}$ 2.3-3.8, another in the $\mathrm{pH}$ range 6.0-7.5 and the last at $\mathrm{pH} 9.2-11$. The two inflections of the curve at $\mathrm{pH} 3.8-6.0$ and 7.5-9.2 indicate that protonation does not occur in this $\mathrm{pH}$ range, and that six protons of the phytic acid had been neutralized. The other four protons of the ligand were neutralized at $\mathrm{pH}$ values above 9.2. The neutralization of the ligand occurred in the $\mathrm{pH}$ range from 2.3 to 11 , and so all of the protonation constants could be calculated from the potentiometric data. The protonation constants of the phytic acid were all considered for the calculation of the systems stability constants with manganese(II) and cobalt(II) ions. ${ }^{40}$

The curve for phytic acid-Mn(II) in a 2:1 molar ratio is below that of phytic acid alone at $\mathrm{pH}$ values above 4.5 , and this decrease becomes more evident from $\mathrm{pH} 5.5$ up to 9.5 (Figure 1). The curve ends at $\mathrm{pH}$ near 10.5. The curve shown in Figure 2 for $\mathrm{Co}$ (II) and the ligand, also in a 2:1 molar ratio, is below that of phytic acid at $\mathrm{pH}$ values above 3.5, and again the decrease is more evident between pH 5.5 and 10.0. Such observations indicate that the phytic acid interacted with both $\mathrm{Mn}$ (II) and $\mathrm{Co}(\mathrm{II})$ ions forming different species in solution.

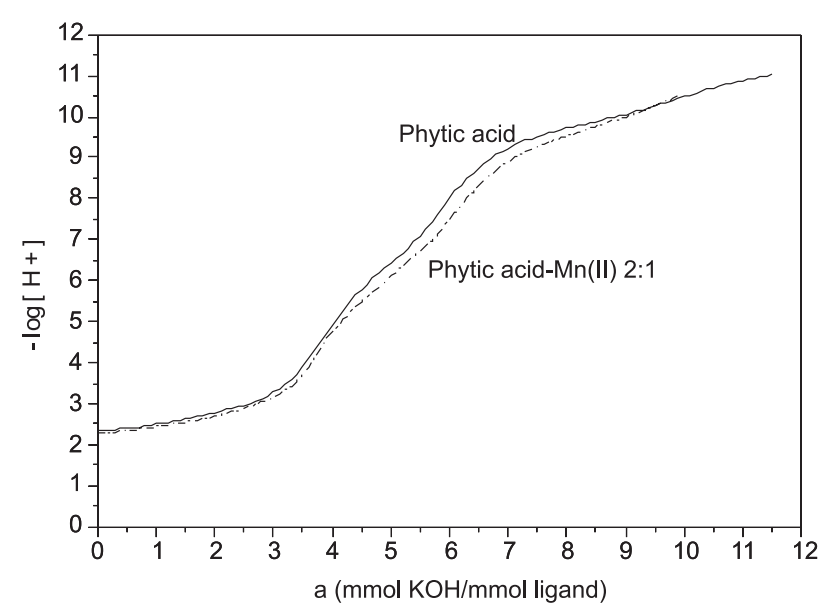

Figure 1. Potentiometric $\mathrm{pH}$ profiles for solutions containing $1.00 \times 10^{-3} \mathrm{~mol} \mathrm{~L}^{-1}$ phytic acid alone; $1.00 \times 10^{-3} \mathrm{~mol} \mathrm{~L}^{-1}$ ligand and $0.50 \times 10^{-3} \mathrm{~mol} \mathrm{~L}^{-1} \mathrm{Mn}(\mathrm{II})$ in the absence of dioxygen; at $36.0 \pm 0.1{ }^{\circ} \mathrm{C}$ and ionic strength $0.100 \mathrm{~mol} \mathrm{~L}^{-1}(\mathrm{KCl})$.

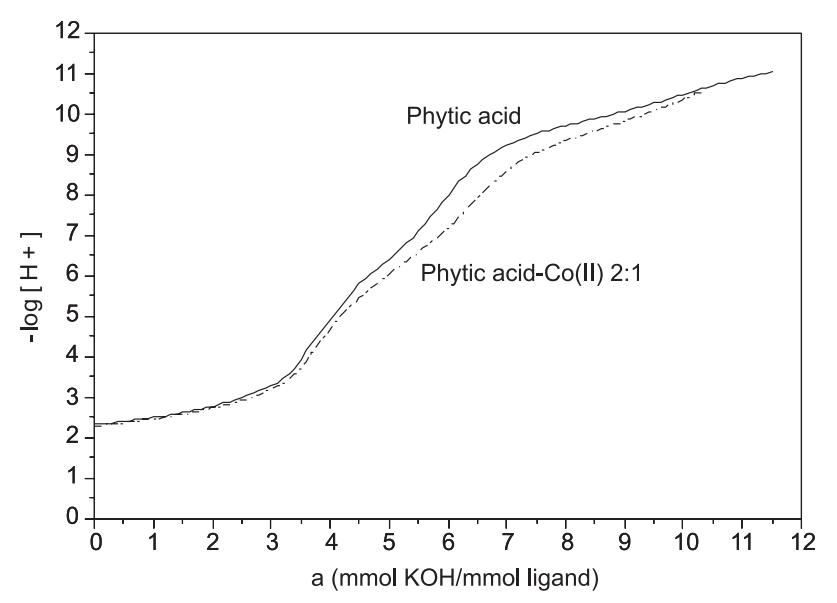

Figure 2. Potentiometric $\mathrm{pH}$ profiles for solutions containing $1.00 \times 10^{-3} \mathrm{~mol} \mathrm{~L}^{-1}$ phytic acid alone; $1.00 \times 10^{-3} \mathrm{~mol} \mathrm{~L}^{-1}$ ligand and $0.50 \times 10^{-3} \mathrm{~mol} \mathrm{~L}^{-1} \mathrm{Co}(\mathrm{II})$ in the absence of dioxygen; at $36.0 \pm 0.1{ }^{\circ} \mathrm{C}$ and ionic strength $0.100 \mathrm{~mol} \mathrm{~L}^{-1}(\mathrm{KCl})$.

\section{Formation constants of the complexes}

Table 1 shows the values of $\log \mathrm{K}$ of the complexes of phytic acid and the cations $\mathrm{Mn}$ (II) and $\mathrm{Co}(\mathrm{II})$. It is verified that for the ML specie of phytic acid-Mn(II) complex $\log \mathrm{K} 10.85$ is presented and for MHL specie a similar value is revealed, $\log \mathrm{K}$ is 10.42 . For the subsequent di, tri, tetra, penta, hexa and heptaprotonated species, the force of interaction between the metal and the ligand reduced as the ligand became more protonated. For the phytic acid-Co(II) complexes the species $\mathrm{MH}_{2} \mathrm{~L}, \mathrm{MH}_{3} \mathrm{~L}, \mathrm{MH}_{4} \mathrm{~L}, \mathrm{MH}_{5} \mathrm{~L}, \mathrm{MH}_{6} \mathrm{~L}$ and $\mathrm{MH}_{7} \mathrm{~L}$ showed a decrease in the $\log \mathrm{K}$ values with the phytic acid becoming more protonated.

\section{Species distribution curves}

Figure 3 shows the species distribution curves for 
Table 1. Logarithms of the stability constants of $\mathrm{Mn}$ (II) and $\mathrm{Co}$ (II) complexes of phytic acid at $36.0 \pm 0.1^{\circ} \mathrm{C}$ and ionic strength $0.100 \mathrm{~mol} \mathrm{~L}^{-1}$ $(\mathrm{KCl})$, measured under argon

\begin{tabular}{lcc}
\hline Equilibrium expression & $\log \mathrm{K} \mathrm{Mn}(\mathrm{II})$ & $\log \mathrm{K} \mathrm{Co}(\mathrm{II})$ \\
\hline$[\mathrm{ML}] /[\mathrm{L}][\mathrm{M}]$ & $10.85(3)$ & $9.73(3)$ \\
{$[\mathrm{MHL}] /[\mathrm{ML}]\left[\mathrm{H}^{+}\right]$} & $10.42(3)$ & $9.73(3)$ \\
{$\left[\mathrm{MH}_{2} \mathrm{~L}\right] /[\mathrm{MHL}]\left[\mathrm{H}^{+}\right]$} & $9.35(3)$ & $9.21(3)$ \\
{$\left[\mathrm{MH}_{3} \mathrm{~L}\right] /\left[\mathrm{MH}_{2} \mathrm{~L}\right]\left[\mathrm{H}^{+}\right]$} & $9.32(2)$ & $8.84(2)$ \\
{$\left[\mathrm{MH}_{4} \mathrm{~L}\right] /\left[\mathrm{MH}_{3} \mathrm{~L}\right]\left[\mathrm{H}^{+}\right]$} & $7.70(3)$ & $7.31(3)$ \\
{$\left[\mathrm{MH}_{5} \mathrm{~L}\right] /\left[\mathrm{MH}_{4} \mathrm{~L}\right]\left[\mathrm{H}^{+}\right]$} & $6.15(2)$ & $6.22(2)$ \\
{$\left[\mathrm{MH}_{6} \mathrm{~L}\right] /\left[\mathrm{MH}_{5} \mathrm{~L}\right]\left[\mathrm{H}^{+}\right]$} & $5.47(3)$ & $5.51(2)$ \\
{$\left[\mathrm{MH}_{7} \mathrm{~L}\right] /\left[\mathrm{MH}_{6} \mathrm{~L}\right]\left[\mathrm{H}^{+}\right]$} & $2.90(2)$ & $3.34(2)$ \\
\hline
\end{tabular}

The average deviation standard for the phytic acid-Mn(II) system is $\sigma$-fit $=0.009938$ and phytic acid-Co(II) system is $\sigma=0.007083$. $\sigma$-fit is the deviation computed from calculated $\mathrm{pH}$ values relative to those observed. ${ }^{38}$

the phytic acid-Mn(II) system. The ML species reached a maximum formation of $96.7 \%$ at $\mathrm{pH} 11.9$, which decreased at lower $\mathrm{pH}$ values, leading to the formation of monoprotonated species, MHL, which reached a maximum formation of $60.4 \%$ at $\mathrm{pH} 10$. The other species: $\mathrm{MH}_{2} \mathrm{~L}$, $\mathrm{MH}_{3} \mathrm{~L}, \mathrm{MH}_{4} \mathrm{~L}, \mathrm{MH}_{5} \mathrm{~L}, \mathrm{MH}_{6} \mathrm{~L}$ and $\mathrm{MH}_{7} \mathrm{~L}$ are the di, tri, tetra, penta, hexa and heptaprotonated ones, respectively, and they reached their maximum formations in the $\mathrm{pH}$ range of 2.6 to 9.3 .

Figure 4 shows the species distribution curves for phytic acid-Co(II) system, the ML species is $99.3 \%$ formed at $\mathrm{pH}$ 11.9. At lower $\mathrm{pH}$ values the concentration of $\mathrm{ML}$ species decreased and the concentration of MHL species increased, reaching a maximum formation of $45.4 \%$ at $\mathrm{pH}$ 9.5. The mono, di, tri, tetra, penta, hexa and heptaprotonted species reached maximum formations in the $\mathrm{pH}$ range of 2.0 to 9.0 .

From Figures 3 and 4, the major species which predominated at $\mathrm{pH}$ 7.0-7.5 can be seen. There are two

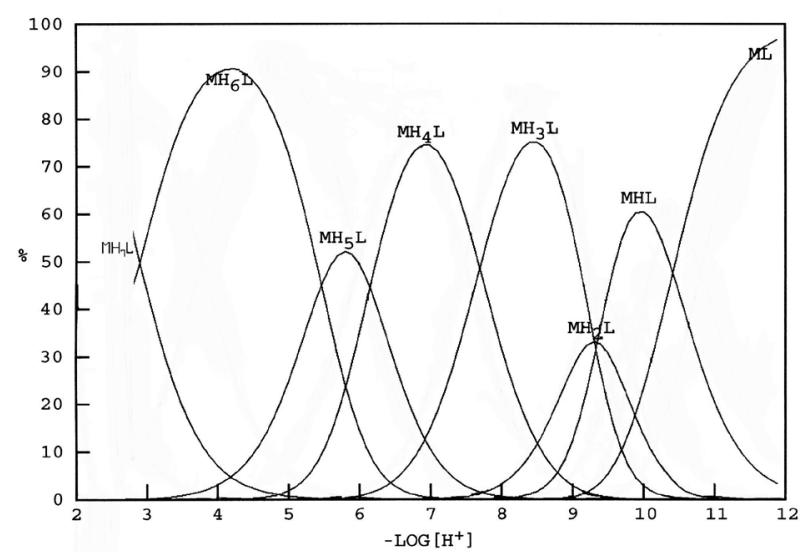

Figure 3. Species distribution curves for a solution containing $1.00 \times 10^{-3} \mathrm{~mol} \mathrm{~L}^{-1}$ phytic acid (L) and $0.5 \times 10^{-3} \mathrm{~mol} \mathrm{~L}^{-1} \mathrm{Mn}$ (II) (M) under anaerobic conditions in aqueous solution at $36.0 \pm 0.1^{\circ} \mathrm{C}$ and ionic strength $0.100 \mathrm{~mol} \mathrm{~L}^{-1}(\mathrm{KCl})$.

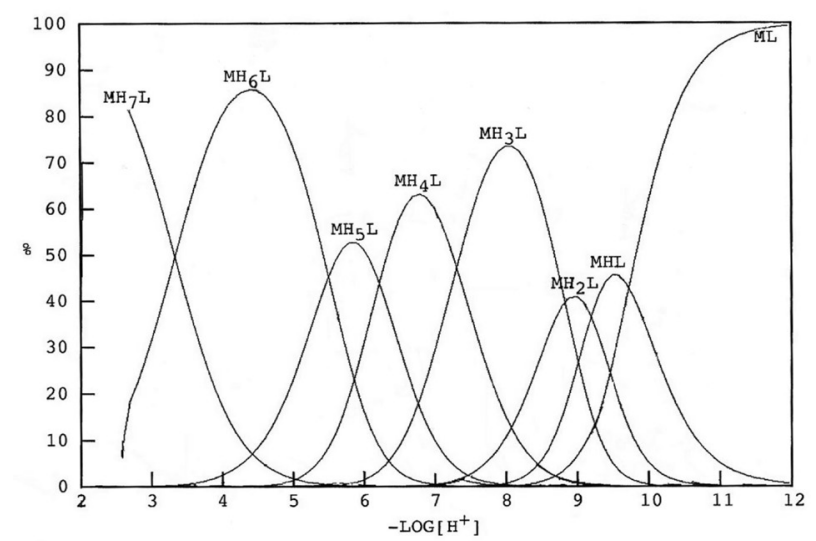

Figure 4. Species distribution curves for a solution containing $1.00 \times 10^{-3} \mathrm{~mol} \mathrm{~L}^{-1}$ phytic acid (L) and $0.5 \times 10^{-3} \mathrm{~mol} \mathrm{~L}^{-1} \mathrm{Co}$ (II) (M) under anaerobic conditions in aqueous solution at $36.0 \pm 0.1{ }^{\circ} \mathrm{C}$ and ionic strength $0.100 \mathrm{~mol} \mathrm{~L}^{-1}(\mathrm{KCl})$.

major species: $\mathrm{MH}_{4} \mathrm{~L}$ and $\mathrm{MH}_{3} \mathrm{~L}$, for both metal systems. Thus, the species $\left[\mathrm{MH}_{4} \mathrm{~L}\right]^{6-}$ for the two metallic ion systems was synthesized in the $\mathrm{pH}$ range 7.0-7.5.

\section{Spectroscopic studies}

The infrared spectroscopic data on the dipotassium salt of phytic acid and its compounds with $\mathrm{Mn}$ (II) and $\mathrm{Co}(\mathrm{II})$ are shown in Figure 5. In the phytic acid dipotassium salt, a medium band at $1647 \mathrm{~cm}^{-1}$ is attributed to the stretching frequencies of the $\mathrm{P}=\mathrm{O}$ groups. A strong band at $1070 \mathrm{~cm}^{-1}$ and a medium one at $996 \mathrm{~cm}^{-1}$ are attributed to the anti-symmetrical and symmetrical frequencies of the $\mathrm{P}-\mathrm{O}-\mathrm{C}$ groups, respectively. ${ }^{41}$ For these complexes the stretching frequencies of the $\mathrm{P}=\mathrm{O}$ groups, as well as the anti-symmetrical and symmetrical frequencies of $\mathrm{P}-\mathrm{O}-\mathrm{C}$ groups, shift to lower or higher frequencies, suggesting interactions between phytic acid and metal ions.

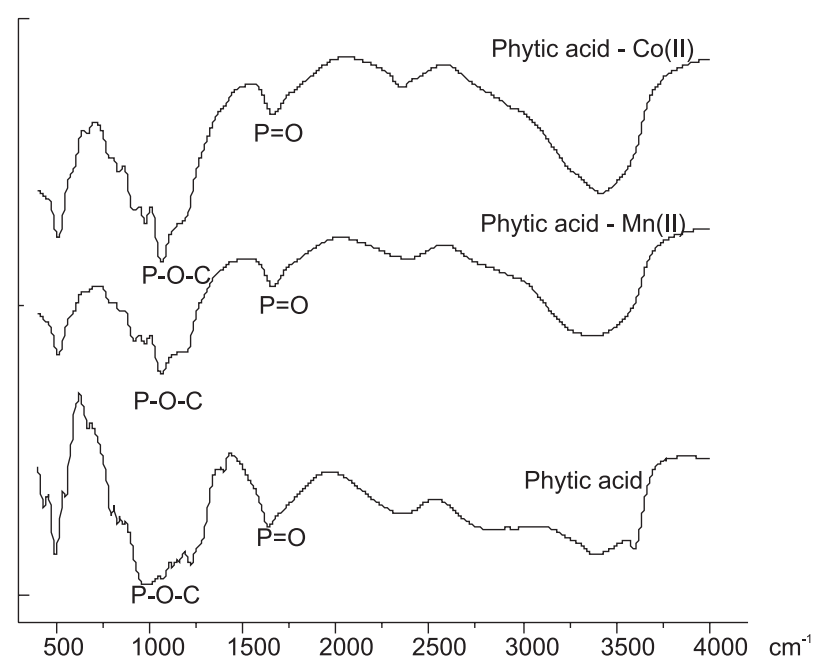

Figure 5. Infrared spectra of the phytic acid, phytic acid Mn(II) and Co(II) complex, specie $\left[\mathrm{MH}_{4} \mathrm{~L}\right]^{6-}$. 


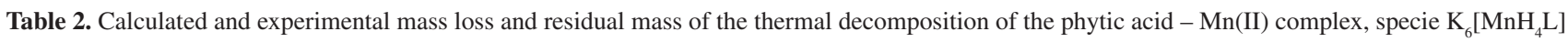

\begin{tabular}{lccc}
\hline Group or molecules lost & \multicolumn{2}{c}{ Mass percentage (\%) } & Temperature range $\left({ }^{\circ} \mathrm{C}\right)$ \\
\cline { 2 - 4 } & Calculated & Experimental & $30-172$ \\
One lattice $\mathrm{H}_{2} \mathrm{O}$ molecules & 2.33 & 2.18 & $173-350$ \\
Five $\mathrm{H}_{2} \mathrm{O}$ molecules of constitution & 11.65 & 11.71 & $351-680$ \\
Six atoms of carbon & 9.31 & 9.51 & 380 \\
\hline
\end{tabular}

Table 3. Calculated and experimental mass loss and residual mass of the thermal decomposition of the phytic acid - $\mathrm{Co}(\mathrm{II}) \mathrm{complex}$, specie $\mathrm{K}_{6}\left[\mathrm{CoH} \mathrm{H}_{4} \mathrm{~L}\right]$

\begin{tabular}{lccc}
\hline Group or molecules lost & \multicolumn{2}{c}{ Mass percentage $(\%)$} & Temperature range $\left({ }^{\circ} \mathrm{C}\right)$ \\
\cline { 2 - 4 } & Calculated & Experimental & $30-180$ \\
\hline $2.5 \mathrm{H}_{2} \mathrm{O}$ lattice molecules & 4.53 & 5.60 & $181-400$ \\
Five $\mathrm{H}_{2} \mathrm{O}$ molecules of constitution & 11.32 & 11.04 & 4.58 \\
Six atoms of carbon & 9.06 & & $401-700$ \\
\hline
\end{tabular}

\section{Thermogravimetric measurements}

The TG/DTG and DSC curves of the compounds are shown in Figures 6-9. These curves show mass losses in steps and thermal events corresponding to these losses. In both TG curves the first mass loss corresponding to the endothermic peak is attributed to dehydration. These curves also show that mass losses can be observed up to $900{ }^{\circ} \mathrm{C}$ with formation of a mixture of pyro and metaphosphate.

For the manganese phytate complex the TG curve in Figure 6 shows mass losses in four steps between 30 and $900{ }^{\circ} \mathrm{C}$. The first step, up to $170^{\circ} \mathrm{C}$, is due to the dehydration with a loss of $1 \mathrm{H}_{2} \mathrm{O}$ (calculated $2.33 \%$; TG $2.18 \%$ ). The anhydrous compound was stable up to $220^{\circ} \mathrm{C}$, and above this temperature the thermal decomposition occurred in three overlapping steps, although the DTG curve shows a large number of consecutive and/or simultaneous steps occurring through a more complex pathway than that observed from the TG curve. The step observed between $220-350{ }^{\circ} \mathrm{C}$, which occurred through a fast process, is attributed to the loss of constitution water corresponding to $5 \mathrm{H}_{2} \mathrm{O}$ (calculated $11.65 \%$; TG $11.71 \%$ ), with formation of double potassium and manganese pyrophosphate and potassium metaphosphate. The mass loss that occurred between $350-680^{\circ} \mathrm{C}$ is ascribed to the oxidation of organic matter (calculated $9.31 \%$; TG 9.51\%). From $680{ }^{\circ} \mathrm{C}$ up to $900{ }^{\circ} \mathrm{C}$ a mass loss is still observed, which is attributed to the loss of potassium metaphosphate. The DSC curve for the manganese phytate complex is shown in Figure 7. This curve shows endothermic peaks at 100 and $200{ }^{\circ} \mathrm{C}$ attributed to losses of hydration and constitution waters, respectively, and in agreement with the first and second steps of the TG curve. The exotherm between 400 and $550{ }^{\circ} \mathrm{C}$, with a peak at $425^{\circ} \mathrm{C}$, is ascribed to the oxidation of the organic matter, corresponding to the third step of the TG curve. The final residue presented a violet color. For the cobalt phytate complex, the TG curve in Figure 8 also shows mass loss in four steps, between 30 and $900{ }^{\circ} \mathrm{C}$ with mass loss still observed. The first step up to $180{ }^{\circ} \mathrm{C}$ is attributed to the loss of $2.5 \mathrm{H}_{2} \mathrm{O}$ (calculated 4.53\%; TG 5.60\%). The anhydrous compound was stable up to $220{ }^{\circ} \mathrm{C}$ and between $220-400{ }^{\circ} \mathrm{C}$ the mass loss is ascribed to the elimination of the constitution water, corresponding to $5 \mathrm{H}_{2} \mathrm{O}$ (calculated $11.32 \%$; TG $11.04 \%$ ) with formation of double potassium and cobalt pyrophosphate and potassium metaphosphate. The mass loss between 400 and $700{ }^{\circ} \mathrm{C}$ is ascribed to the oxidation of the organic matter (calculated $9.06 \%$; TG $8.58 \%$ ). The mass loss above $700{ }^{\circ} \mathrm{C}$ is attributed to the elimination of potassium metaphosphate. The DSC curve of the cobalt complex, Figure 9, shows endothermic peaks at 130 and $325^{\circ} \mathrm{C}$ attributed to dehydration and loss of constitution water, respectively. The broad exothermic peak at $500^{\circ} \mathrm{C}$

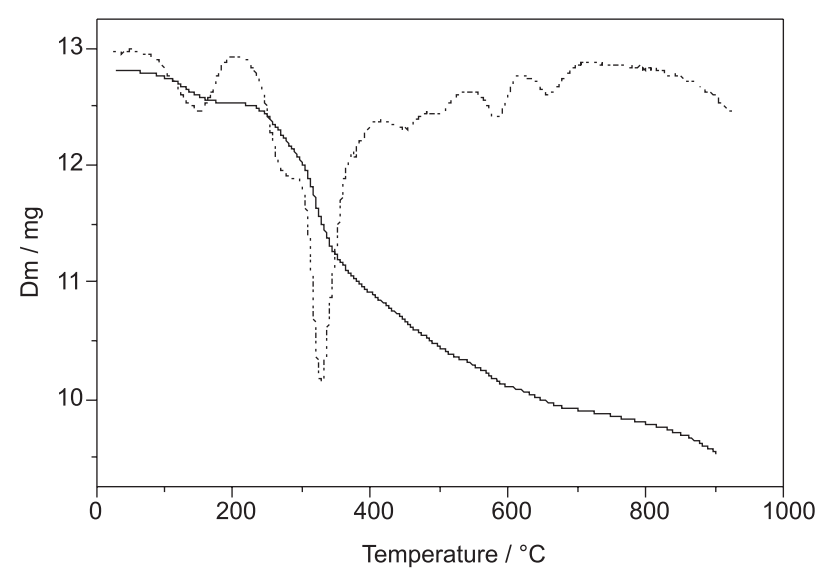

Figure 6. TG and DTG curves for phytic acid-Mn(II) complex, species $\left[\mathrm{MH}_{4} \mathrm{~L}\right]^{6-}$, obtained in a dynamic synthetic air atmosphere, $50 \mathrm{~mL} \mathrm{~min}^{-1}$ flow, room temperature to $900{ }^{\circ} \mathrm{C}, 20{ }^{\circ} \mathrm{C} \mathrm{min}-1$ heating rate, $\alpha-\mathrm{Al}_{2} \mathrm{O}_{3}$ support. 
is ascribed to the oxidation of the organic matter and sharp exothermic peaks at 310 and $560{ }^{\circ} \mathrm{C}$ are attributed to the physical phenomena, probably crystalline transitions. At

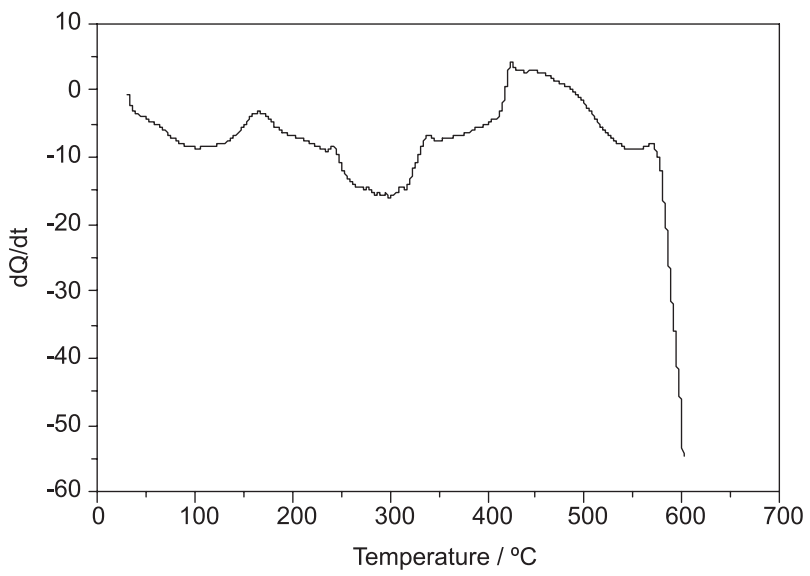

Figure 7. DSC curve for phytic acid-Mn(II) complex, obtained in dynamic synthetic air atmosphere with $50 \mathrm{mLmin}^{-1}$ flow, room temperature to $600{ }^{\circ} \mathrm{C}, 20^{\circ} \mathrm{C} \mathrm{min}^{-1}$ heating rate, $\alpha-\mathrm{Al}_{2} \mathrm{O}_{3}$ support.

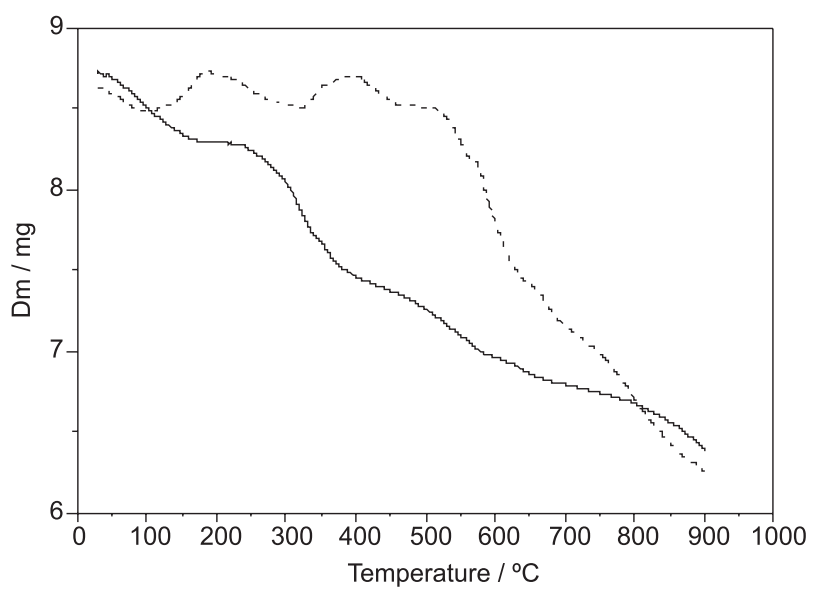

Figure 8. TG and DTG curves for phytic acid-Co(II) complex, species $\left[\mathrm{MH}_{4} \mathrm{~L}\right]^{6-}$, obtained in dynamic synthetic air atmosphere, $50 \mathrm{~mL} \mathrm{~min}^{-1}$ flow, room temperature to $900{ }^{\circ} \mathrm{C}, 20^{\circ} \mathrm{C} \mathrm{min}-1$ heating rate, $\alpha-\mathrm{Al}_{2} \mathrm{O}_{3}$ support.

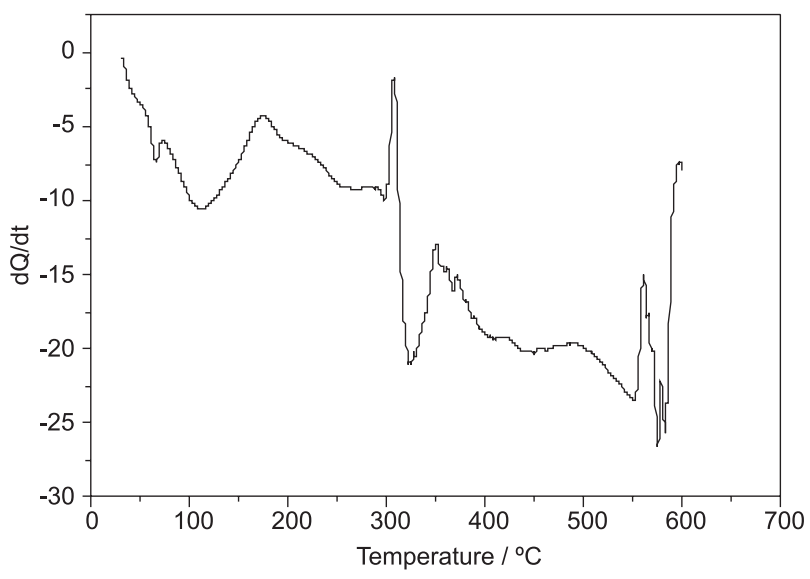

Figure 9. DSC curve for phytic acid-Co(II) complex, obtained in dynamic

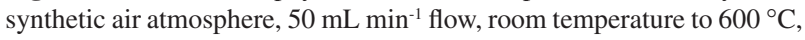
$20^{\circ} \mathrm{C} \mathrm{min}^{-1}$ heating rate, $\alpha-\mathrm{Al}_{2} \mathrm{O}_{3}$ support. the end of the thermal analysis, the residue in the crucible had a blue color indicating that the oxidation state is not modified and that the formation of metaphosphate $\mathrm{Co}$ (II) is probable.

\section{Conclusions}

The potentiometric study of two systems allows the accurate verification of $\mathrm{pH}$ at which the phytic acid coordinates with the metallic ions. Results provide evidence of strong chelating action of phytic acid in relation to the $\mathrm{Mn}(\mathrm{II})$ and $\mathrm{Co}(\mathrm{II})$ ions. The species distribution curves of these systems were determined and they will be used to choose the appropriate $\mathrm{pH}$ values at which synthesis will be performed. The infrared spectroscopic data suggests interactions between phytic acid and bivalent manganese and cobalt. The TG/DTG and DSC curves provided information on the thermal stability and thermal decomposition of the complexes. The TG curves also showed that mass losses were still observed up to $900{ }^{\circ} \mathrm{C}$, with formation of pyro and metaphosphate. The DSC obtained from phytic acidCo(II) complex, showed a physical phenomena that was not observed from phytic acid-Mn(II) complex. The residue obtained from thermal analysis, indicated that the $\operatorname{Co}(\mathrm{II})$ oxidation state was not modified, with probable formation of metaphosphate $\mathrm{Co}(\mathrm{II})$.

\section{Acknowledgments}

The authors are grateful to the financial support of the CAPES.

\section{References}

1. Raboy, V.; Phytochemistry 2003, 64, 1033.

2. De Boland, A. R.; Garner, G. B.; O'del, B.; J. Agric. Food Chem. $\mathbf{1 9 7 5}, 23,1166$.

3. Williams, S. G. Plant Physiol. 1970, 45, 376.

4. St. Angelo, A. J.; Crit. Rev. Food Sci. Nutr. 1996, 36, 175.

5. Lee, B. J.; Hendricks, D. G.; J. Food Sci. 1995, 60, 241.

6. Tsao, G. T.; Zheng, Y.; Lu, J.; Gong, C. S.; Appl. Biochem. Biotechnol. 1997, 63, 731.

7. Notoya, T.; Otieno-Alego, V.; Schweinsberg, P.; Corros. Sci. 1995, 37, 55 .

8. Jo, S.; Jeong, H.; Bae, S. R., Jeon, S.; Microchem. J. 2008, 88, 1 .

9. Erdman, J. W.; J. Am.Oil Chem. Soc. 1979, 56, 736.

10. Graf, E.; J. Am.Oil Chem. Soc. 1983, 60, 1861.

11. Le François, P.; J. Food Compos. Anal. 1988, 1, 139.

12. Midorikawa, K.; Murata, M.; Oikawa, S.; Hiraku, Y.; Kawanishi, S.; Biochem. Biophys. Res. Commun. 2001, $288,552$. 
13. Shears, S. B.; Cell. Signal. 2001, 13, 151.

14. Oatway, L.; Vasanthan, T.; Helm, J. H.; Food Rev. Int. 2001, 7, 419.

15. Greiner, R.; Konietzny, U.; Jany, K-D; J. Ernährungsmedizin 2006, 8, 18.

16. Grases, F.; Sanchos, P.; Costa-Bauzá, A.; Bonnin, O.; Isern, B.; Perelló, J.; Prieto, R. M.; Cardiovasc. Pathol. 2008, 17, 139.

17. Xu, Q.; Kanthasamy, A. G.; Reddy, M. B.; Toxicology 2008 , $245,101$.

18. Isbrandt, L. R.; Oertel, R. P.; J. Am. Chem. Soc. 1980, 102, 3144.

19. Barrientos, L. G.; Murthy, P. P. N.; Carbohydr. Res. 1996, 296, 39.

20. Paton, G.; Noailly, M.; Mossoyan, J. C.; J. Phys. Org. Chem. 1999, 12, 401.

21. Plaami, S. Lebensm.-Wissu. Technol. 1997, 30, 633.

22. Cheryan, M.; Crit. Rev. Food Sci. Nutr. 1980,13, 297.

23. Person, H.; Tûrk, M.; Nyman, M.; Sandberg, A. S.; J. Agric. Chem. 1998, 46, 3194.

24. De Stefano, C.; Milea, D.; Sammartano, S.; J. Chem. Eng. 2003, 48,114 .

25. De Stefano, C.; Milea, D.; Sammartano, S.; Thermochim. Acta 2004, 423, 63.

26. Paddon, C. A.; Marken, F.; Electrochem. Commun. 2004, 6, 1249.

27. Yang, H. F.; Feng, J.; Liu, Y. L.; Zhang, Z.; Shen, G.; Yu, R.; J. Phys. Chem. B. 2004, 108, 17412.

28. Rodrigues-Filho, U. P.; Vaz Jr., S.; Felicissimo, M. P.; Scarpellini, M.; Daniel, C.; Vinhas, R. C. J.; Landers, R.; Schneider, J. F.; Mcgarvey, B. R.; Andersen, M. L.; Skibsted, L. H.; J. Inorg. Biochem. 2005, 99, 1973.

29. Torres, J.; Domínguez, S.; Cerdá, M. F.; Obal, G.; Mederos, A.; Irvine, R. F.; Díaz, A.; Kremer, C.; J. Inorg. Biochem. 2005, 99 , 828.
30. De Stefano, C.; Milea, D.; Porcino, N.; Sammartano, S.; J. Agric. Food Chem. 2006, 54, 1459.

31. De Stefano, C.; Milea, D.; Porcino, N.; Sammartano, S.; Anal. Bioanal. Chem. 2006, 386, 346.

32. Crea, P.; De Robertis, A.; De Stefano, C.; Sammartano, S.; Biophys. Chem. 2006, 124, 18.

33. Crea, P.; De Stefano, C.; Milea, D.; Porcino, N.; Sammartano, S.; Biophys. Chem. 2007, 128, 176.

34. Torres, J.; Veiga, N.; Gancheff, J. S.; Domínguez, S.; Mederos, A.; Sundberg, M.; Sánchez, A.; Castiglioni, J.; Díaz, A.; Kremer, C.; J. Mol. Struct. 2008, 874, 77.

35. Crea, F.; De Stefano, C.; Milea, D.; Sammartano, S.; Coord. Chem. Rev. 2008, 252, 1108.

36. Crea, F.; De Stefano, C.; Milea, D.; Sammartano, S.; J. Solution Chem. 2009, 38, 115.

37. Schwarzenbach, G.; Flaschka, H. A.; Complexometric Titration, Ed. Methuen Co: London, 1969.

38. Martell, A. E.; Motekaitis, R. J.; The Determination and Use of Stability Constants, $2^{\text {nd }}$ Ed., VCH Publishers: New York, 1992.

39. Baes, C. F.; Mesmer, R. E.; The Hydrolysis of Cations, Wiley Interscience: New York, 1976.

40. De Carli, L.; Rosso, N. D.; Schnitzler, E.; Carneiro, P. I. B.; Ciênc.Tecnol. Aliment. 2006, 26, 19.

41. Bellamy. L. J.; The Infra-red Spectra of Complex Molecules, $3^{\text {rd }}$ Ed., Chapman and Hall: London, 1975.

Received: December 5, 2008

Web Release Date: August 28, 2009

FAPESP helped in meeting the publication costs of this article. 